\title{
Synthesis of LY503430 by using a selective rearrangement of $\beta$-amino alcohols induced by DAST
}

\author{
Béranger Duthion, Domingo Gomez Pardo, ${ }^{*}$ and Janine Cossy ${ }^{*}$ \\ Laboratoire de Chimie Organique, ESPCI ParisTech, CNRS, \\ 10, Rue Vauquelin, 75231 Paris Cedex 05, France \\ E-mail:domingo.gomez-pardo@espci.fr,janine.cossy@espci.fr
}

Dedicated to Professor Pierre Vogel on the occasion of his $70^{\text {th }}$ birthday

DOI: http://dx.doi.org/10.3998/ark.5550190.p008.252

\begin{abstract}
LY503430, an optically active $\beta$-fluoroamine, is a potential therapeutic agent for the Parkinson's disease. Different strategies have been studied to synthesize this molecule using a regioselective and stereospecific rearrangement of $\beta$-amino alcohols into $\beta$-fluoroamines induced by DAST. This reaction allowed the synthesis of LY503430 with an excellent enantiomeric excess.
\end{abstract}

Keywords: Rearrangement, $\beta$-amino alcohols, DAST, $\beta$-fluoroamines, LY503430

\section{Introduction}

LY503430, an optically active $\beta$-fluoroamine, which is a potential therapeutic agent for the Parkinson's disease, ${ }^{1}$ has been prepared by Eli Lilly on gram scale ${ }^{2}$ as well as on a kilogram scale $^{2}$ from racemic $\beta$-fluoroamine $( \pm)$-A. The two enantiomers of $\mathbf{A}$ were separated by using chiral chromatography or diastereomeric salt resolution (Scheme 1).

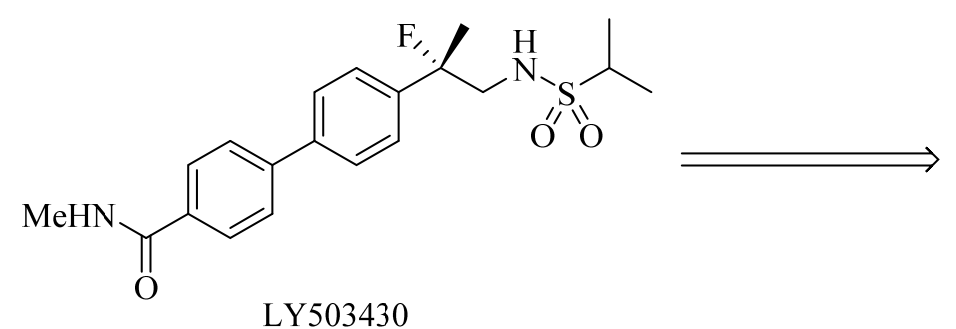

LY503430<smiles>CC(F)(CN)c1ccc(I)cc1</smiles>

$( \pm)-\mathbf{A}$

Scheme 1. Retrosynthesis analysis of LY503430 by Eli Lilly. 
Recently, we have reported that $N, N$-dialkyl $\beta$-amino alcohols B can be enantioselectively and regioselectively rearranged to $\beta$-fluoroamines $\mathbf{C}$ by treatment with $N, N$-diethylaminosulfur trifluoride $(\mathrm{DAST})^{3}$ in excellent yield and enantiomeric excess (Scheme 2). ${ }^{4}$

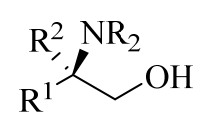

B

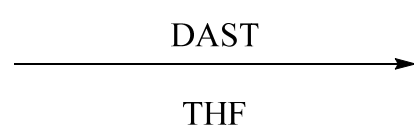

THF

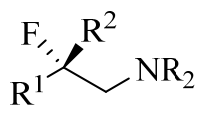

C

Scheme 2. Stereospecific rearrangement of $\beta$-amino alcohols $\mathbf{B}$ to fluoroamines $\mathbf{C}$.

Here, we would like to report our synthetic efforts toward the synthesis of LY503430 by considering the rearrangement of $\beta$-amino alcohols $\mathbf{B}$ as the key step to introduce the $\beta$-fluoroamino moiety present in LY503430. Our efforts have culminated to the total synthesis of this biologically active compound. ${ }^{4}$

\section{Results and Discussion}

\section{First strategy}

Our first synthetic strategy relies on a very late Suzuki cross-coupling of triflate D with a boronic acid to produce the biarylic substituent present in LY503430. The synthesis of $\beta$-fluoroamine D has been envisaged by utilizing an enantioselective rearrangement of $\beta$-amino alcohol $\mathbf{E}$ induced by DAST. A diastereoselective alkylation of $\mathbf{F}$ was chosen to control the quaternary stereocenter present in $\mathbf{E}$ and the synthesis of $\mathbf{F}$ was planned from 4-hydroxy-D-phenylglycine (Scheme 3).<smiles>CNC(=O)c1ccc(-c2ccc(C(C)(F)CNS(=O)(=O)C(C)C)cc2)cc1</smiles>

LY503430<smiles>N[C@@H](C(=O)O)c1ccc(O)cc1</smiles>

4-Hydroxy-D-phenylglycine

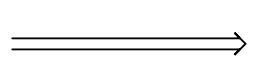

$\mathrm{RO}$<smiles>[Y10]CC(C)(F)c1ccc(Cl)cc1</smiles>

D<smiles>[R6]Oc1ccc([C@H]2C(=O)O[C@@H](c3ccccc3)N2C(C)=O)cc1</smiles>

$\mathbf{F}$<smiles>[R14]NC(C)(CO)c1ccc([R20])cc1</smiles>

$\mathbf{E}$

Scheme 3. First retrosynthesis analysis of LY503430. 
The synthesis of LY503430 started with the preparation of oxazolidinone 4 in four steps (Scheme 4). 4-Hydroxy-D-phenylglycine was treated with two equivalents of methylchloroformate $\left(\mathrm{NaOH} / \mathrm{H}_{2} \mathrm{O}\right)$ to furnish carbamate $\mathbf{1}$ and this carbamate was then transformed to a mixture of oxazolidinones $\mathbf{2}$ and $\mathbf{2}$ ' in a ratio of 5/1, by using benzaldehyde dimethyl acetal under acidic conditions $\left(\mathrm{BF}_{3} \cdot \mathrm{Et}_{2} \mathrm{O}, \mathrm{CH}_{2} \mathrm{Cl}_{2}, 0{ }^{\circ} \mathrm{C}\right) .{ }^{5}$ These two diastereoisomers were separated by chromatography on silica gel and compound $\mathbf{2}$ was isolated with an overall yield of $55 \%$ for the two steps. To control the quaternary center present in $\mathbf{4}$, oxazolidinone $\mathbf{2}$ was methylated. Depending on the conditions, the yield in 3 varied from $30 \%$ to $93 \%$. Indeed, when 2 was treated with LDA (THF, $-78{ }^{\circ} \mathrm{C}$ ) followed by the addition of MeI, a degradation of the starting material was observed. The yield in 3 was improved to 31\% when LDA was replaced by LiHMDS (THF, $-78^{\circ} \mathrm{C}$ ) utilizing methyl iodide as the alkylating agent. When methyl iodide was replaced by methyl triflate, the yield in 3 reached $93 \%$ and the diastereoselectivity was up to 95/5. After reduction of 3 by L-selectride (10 equiv, THF, rt), oxazolidine 4 was formed in $74 \%$ yield, probably via intermediate $\mathbf{G}$ and $\mathbf{G}$ ' (Scheme 4).

In order to obtain compound $\mathbf{8}$, the protected amino alcohol $\mathbf{4}$ was saponified ( $\mathrm{LiOH}$, EtOH $/ \mathrm{H}_{2} \mathrm{O} 1: 1$, reflux) and a $N, N$-dibenzylation as well as the $O$-benzylation were tried $[\mathrm{BnBr}$ (3.1 equiv), $\mathrm{K}_{2} \mathrm{CO}_{3}$, acetone, reflux]. Unfortunately, the desired amino alcohol 8 was not formed but instead tribenzylamine $\mathbf{6}$ was isolated, probably due to the formation of a tribenzylammonium phenolate intermediate $\mathbf{H}$ which has the propensity to eliminate the ammonium group (Scheme 5). To avoid this elimination, compound 4 was $N$ - and $O$-benzylated $\left(\mathrm{BnBr}, \mathrm{K}_{2} \mathrm{CO}_{3}, \mathrm{MeCN}\right.$, reflux) and then treated with $\mathrm{LiOH}$ (aqueous EtOH) to furnish 7 which after $\mathrm{N}$-benzylation afforded the desired amino alcohol $\mathbf{8}$, however in a very poor yield, e.g. $5 \%$ over the three steps due to the poor conversion of oxazolidinone $\left(\tau_{\mathrm{c}}=15 \%\right)$ to produce 7 during the saponification step. As the non-protection of the phenol functionnality in one hand, and the protection of the amine on the other hand, revealed to be problematic during the transformation of oxazolidinone $\mathbf{4}$ to amino alcohol $\mathbf{8}$, we decided to prepare the protected oxazolidinone $\mathbf{9}$. Thus, 4 was selectively $O$-benzylated $\left(\mathrm{BnBr}, \mathrm{K}_{2} \mathrm{CO}_{3}\right.$, acetone, reflux), and the resulting oxazolidinone 9 (93\%) was treated with $\mathrm{LiOH}$ to produce amino alcohol 10 with a total conversion. Finally, after $N, N$-dibenzylation of $\mathbf{1 0}\left(\mathrm{K}_{2} \mathrm{CO}_{3}, \mathrm{BnBr}, \mathrm{MeCN}\right.$, reflux $)$, the desired amino alcohol 8 was isolated in $77 \%$ yield over the last two steps with an enantiomeric excess of 94\% (Scheme 5).

The key intermediate in the synthesis of LY503430, amino alcohol 8 (ee 94\%), was then submitted to DAST to produce $\beta$-fluoroamine 11 in 99\% yield (Scheme 6). However, each attempt to purify 11 either on silica gel or alumina resulted in its degradation. Furthermore, a partial racemization occured during the process as the enantiomeric excess of $\mathbf{1 1}$ revealed to be only $24 \%$. This racemization can be explained by the participation of the electronically enriched benzylated phenol group to the opening of an aziridinium intermediate, ${ }^{6}$ intermediate $\mathbf{I}$, formed after activation of the hydroxy group of amino alcohol $\mathbf{8}$ by DAST. Thus, the racemization proceeds probably through the formation of the achiral intermediate $\mathbf{J}$ (Scheme 6). 


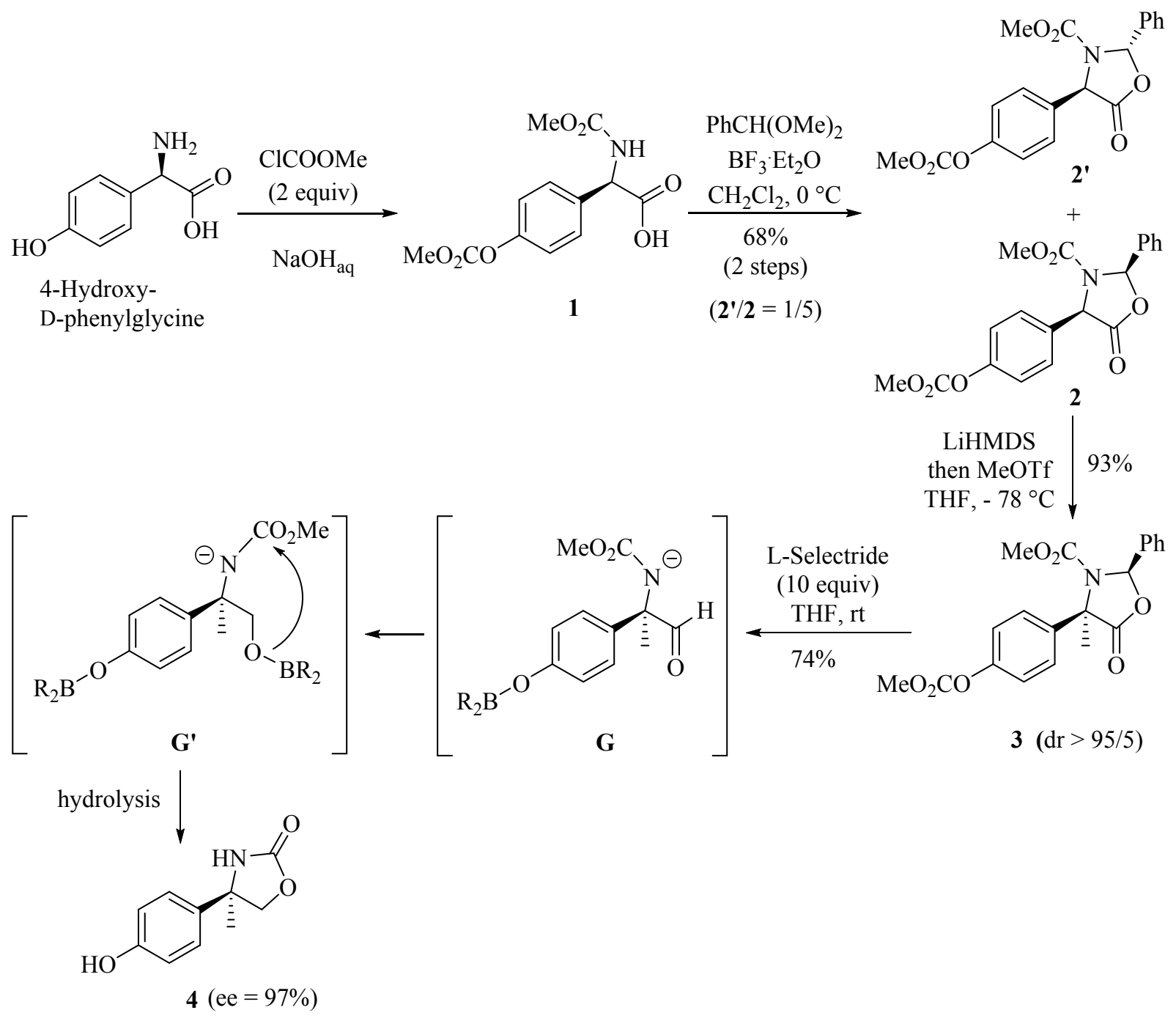

Scheme 4. Synthesis of oxazolidinone 4

Due to the difficulties encountered to access $\beta$-fluoroamine 11 with good enantiomeric excess related to the racemization occurring during the rearrangement of amino alcohol $\mathbf{8}$ induced by DAST, a second strategy was planned to synthesize LY503430. 


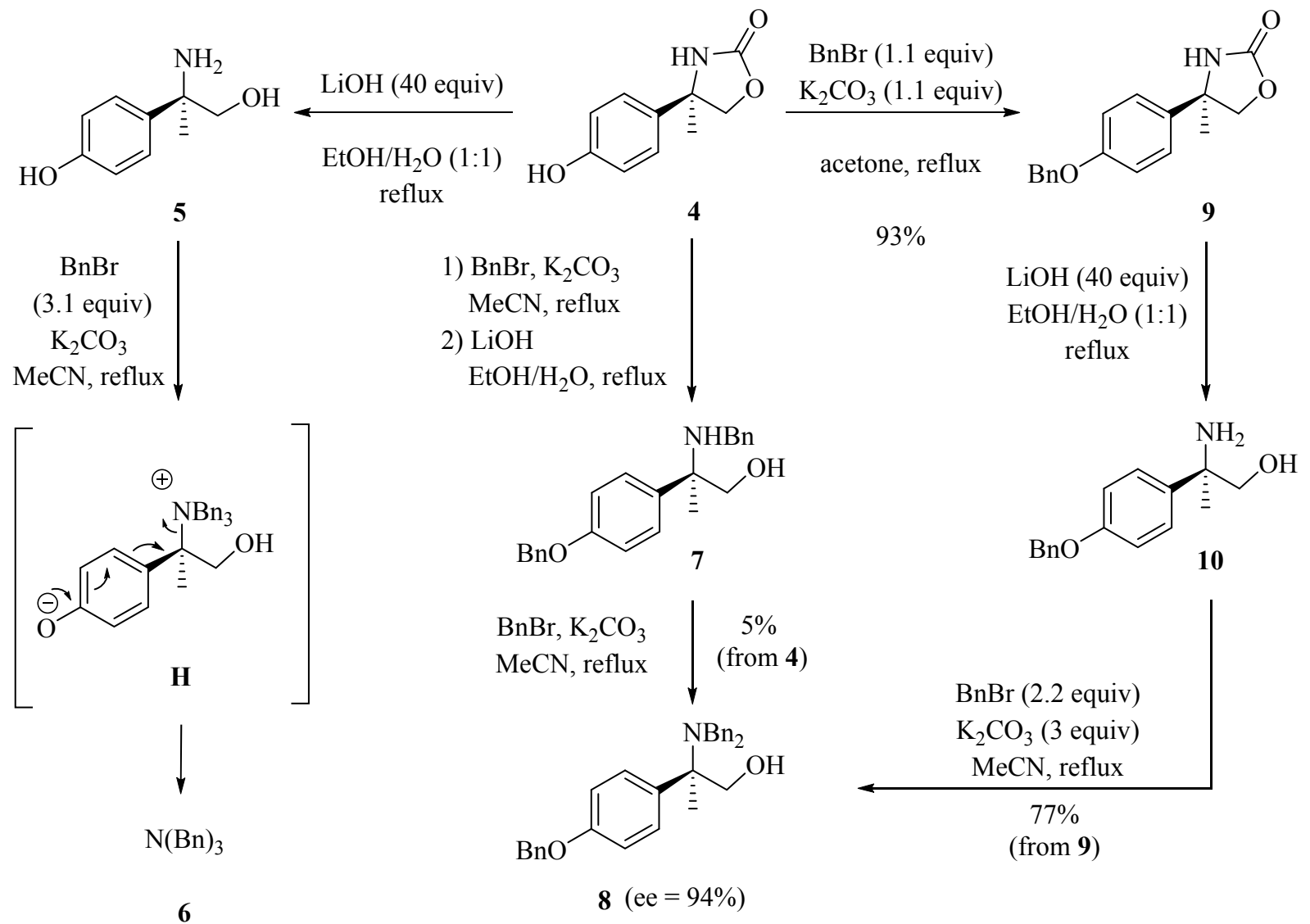

Scheme 5. Synthesis of $\beta$-amino alcohol 8.<smiles>CC(C)(C)Oc1ccc([C@H]([15NH2])CO)cc1</smiles>

$8(\mathrm{ee}=94 \%)$<smiles>[Y][AsH2]</smiles><smiles>C[C@@]1(c2ccc(OCc3ccccc3)cc2)C[C@@H]1Br</smiles>

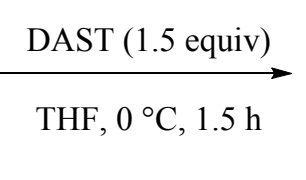

$99 \%$
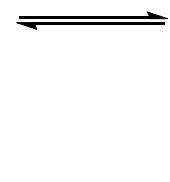<smiles>C[C@@](F)(CN[13CH2])c1ccc(OCc2ccccc2)cc1</smiles>

$11(\mathrm{ee}=24 \%)$ purification on silica gel or alumina)

Scheme 6. Synthesis of $\beta$-fluoroamine 11 . 


\section{Second strategy}

To avoid the racemization during the rearrangement of an amino alcohol by DAST, the synthesis of LY503430 was envisaged by introducing the biphenyl group, possessing an electronwithdrawing substituent, in an early stage of the synthesis of LY503430, before applying the rearrangement induced by DAST. Thus, $\mathbf{4}$ would be transformed to $\mathbf{K}$ which would be rearranged to $\mathbf{L}$, precursor of LY503430 (Scheme 7).

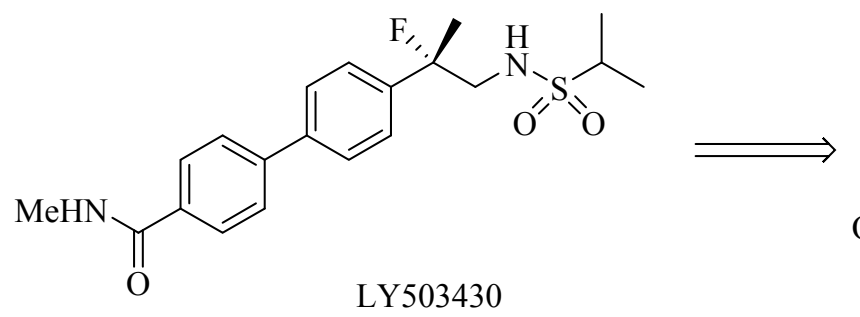<smiles>[R16]CC(C)(F)c1ccc(-c2ccc(C([R])=O)cc2)cc1</smiles><smiles>O=C1NC(c2ccc(O)cc2)CO1</smiles>

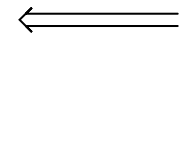<smiles>[R]C(=O)c1ccc(-c2ccc(C([Y20])(C)CO)cc2)cc1</smiles>

Scheme 7. Second retrosynthesis analysis of LY503430.

$\mathrm{N}, \mathrm{N}$-Dibenzyl amino alcohol $\mathbf{1 6}$ (compound of type $\mathbf{K}$ ) was synthesized in four steps. At first, oxazolidinone 4 (ee 97\%) was transformed to the corresponding triflate $12\left(\mathrm{Tf}_{2} \mathrm{O}, \mathrm{Py}, \mathrm{rt}\right.$ ) and after a Suzuki coupling with boronic acid $\mathbf{1 3}\left[\mathrm{K}_{3} \mathrm{PO}_{4} \cdot \mathrm{H}_{2} \mathrm{O}\right.$ (3 equiv), $\mathrm{Pd}(\mathrm{OAc})_{2}(5 \mathrm{~mol} \%)$, XPhos (12.5 mol \%), THF, $\left.100{ }^{\circ} \mathrm{C}, 12 \mathrm{~h}, \mathrm{MW}\right]^{7}$ the biarylic derivative 14 was produced. After treatment of 14 with $\mathrm{LiOH}$ and esterification of the formed carboxylic acid $\left(\mathrm{SOCl}_{2}, \mathrm{MeOH}\right)$, the obtained methyl ester 15 was $N, N$-dibenzylated $\left(\mathrm{K}_{2} \mathrm{CO}_{3}, \mathrm{BnBr}, n-\mathrm{Bu} \mathrm{HII}_{4}, \mathrm{MeCN}\right.$, reflux) to produce 16 in $55 \%$ overall yield. Compound 16 was then submitted to DAST (THF, $0{ }^{\circ} \mathrm{C}$ ) and transformed to the desired $\beta$-fluoroamine 17 (78\%). At this stage, the $N, N$-dibenzyl protecting group revealed to be troublesome as its removal using $\mathrm{H}_{2}$ (1 atm), $\mathrm{Pd} / \mathrm{C}$ in $\mathrm{MeOH} / \mathrm{EtOAc}$ did not produce the desired fluoroamine $\mathbf{1 8}$ but resulted in the degradation of the starting material. The use of $\mathrm{Pd} / \mathrm{C}$ or $\mathrm{Pd}(\mathrm{OH})_{2}$ with $\mathrm{AcOH}$ (5 equiv) in EtOH led to a complex mixture from which the defluorinated derivative 19 was identified (Scheme 8). 

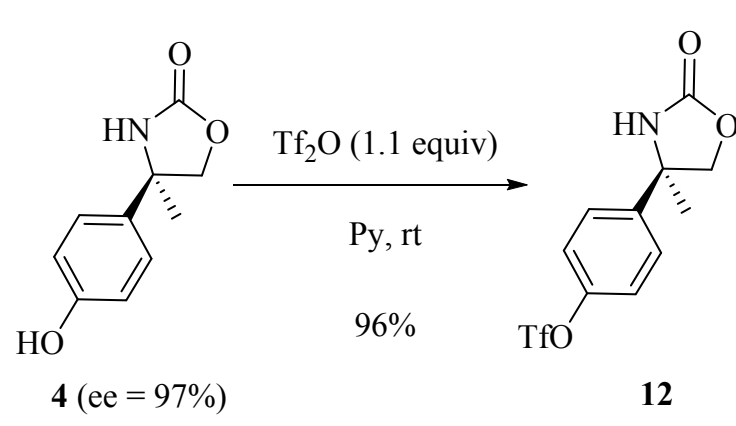

12

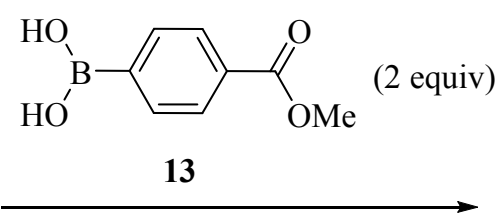

$\mathrm{K}_{3} \mathrm{PO}_{4} \cdot \mathrm{H}_{2} \mathrm{O}$ (3 equiv) $\mathrm{Pd}(\mathrm{OAc})_{2}(5 \mathrm{~mol} \%)$

XPhos (12.5 mol \%)

THF, $100{ }^{\circ} \mathrm{C}, 12 \mathrm{~h}, \mathrm{MW}$

$80 \%$

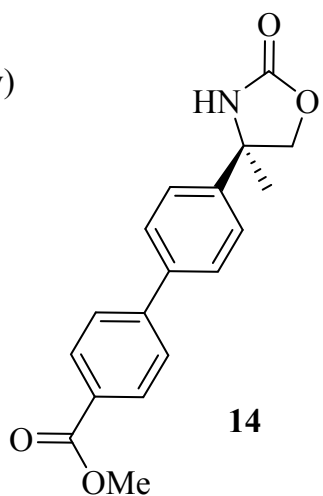

14

1) $\mathrm{LiOH}, \mathrm{EtOH} / \mathrm{H}_{2} \mathrm{O}$

2) $\mathrm{SOCl}_{2}, \mathrm{MeOH}$

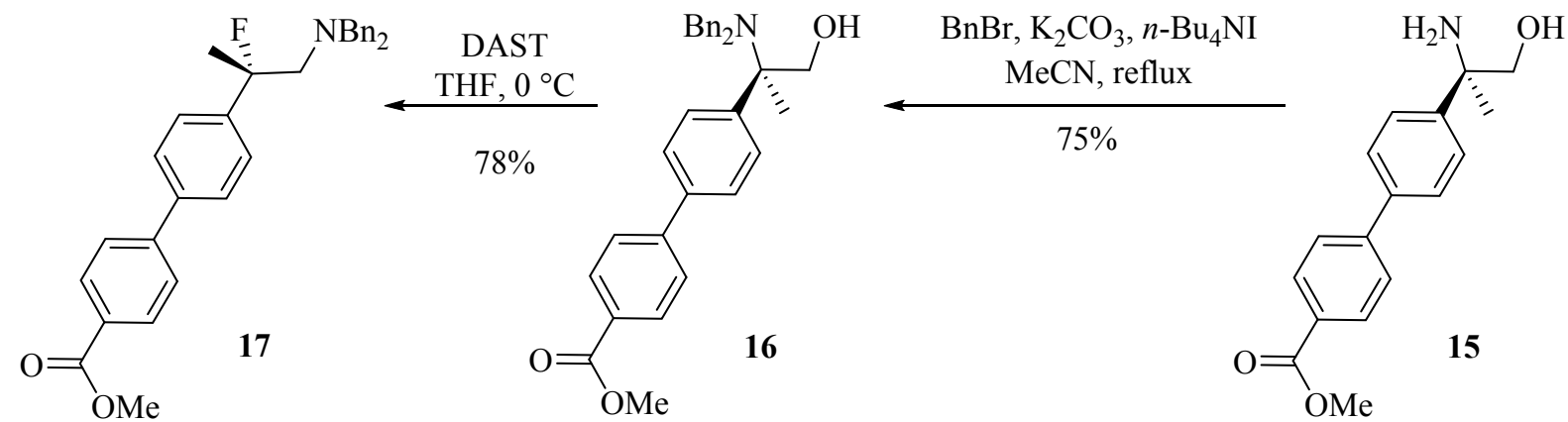

$\mathrm{Pd}(\mathrm{OH})_{2}, \mathrm{H}_{2}(1 \mathrm{~atm})$

$\mathrm{AcOH}$ (5 equiv), EtOH

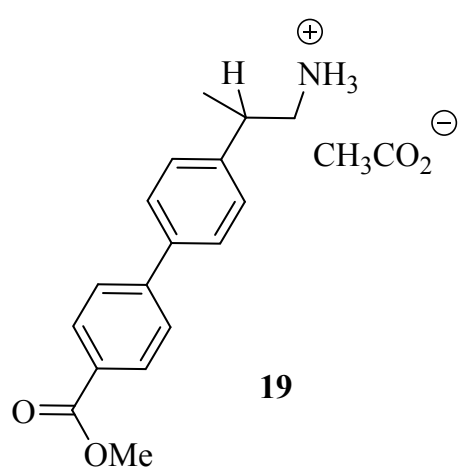

$10 \% \mathrm{Pd} / \mathrm{C}, \mathrm{H}_{2}$ (1 atm)

$\mathrm{AcOH}$ (5 equiv), EtOH

$\mathrm{MeOH} / \mathrm{EtOAc}$<smiles>COC(=O)c1ccc(-c2ccc([C@@](C)(F)CN)cc2)cc1</smiles>

$\mathrm{OMe}$

Scheme 8. Synthesis of $\beta$-fluoroamine 17 . 
As the deprotection of the $N, N$-dibenzyl group seems to be problematic, the use allyl groups to protect the amino group in $\mathbf{1 5}$ was planned. In consequence, $\beta$-amino alcohol $\mathbf{1 5}$ was transformed to $N, N$-diallyl amino alcohol 20 in $87 \%$ yield (AllylBr, $\mathrm{K}_{2} \mathrm{CO}_{3}, n$-Bu $\mathrm{Bu}_{4}, \mathrm{MeCN}$, reflux). The rearrangement of $N, N$-diallyl amino alcohol 20 induced by DAST (1.1 equiv) in THF $\left(0{ }^{\circ} \mathrm{C}, 1 \mathrm{~h}\right)$ furnished the desired fluoroamine $21(88 \%)$ and the amine was then deprotected by treatment with $N, N$-dimethyl barbituric acid (NMDBA) in the presence of $\mathrm{Pd}\left(\mathrm{PPh}_{3}\right)_{4}$ in $\mathrm{CH}_{2} \mathrm{Cl}_{2}{ }^{8}$ leading to $\beta$-fluoroamine 22 (73\% yield). To complete the synthesis of LY503430 from 22, this compound was sulfonylated ( $i-\mathrm{PrSO}_{2} \mathrm{Cl}$ (1.5 equiv), $\mathrm{Et}_{3} \mathrm{~N}$ (3 equiv), $\mathrm{CH}_{2} \mathrm{Cl}_{2}$ ) and the desired sulfonamide $\mathbf{2 3}$ was isolated with a moderate yield of $30 \%$ due to the limited conversion of $22\left(\tau_{\mathrm{c}}=44 \%\right)$. The last step to obtain LY503430 consisted of the transformation of the ester group in 23 to a methyl amide. A one-step procedure using either $\mathrm{MeNH}_{2}$ in EtOH or MeAlCINHMe (obtained by reaction of $\mathrm{AlMe}_{3}$ with $\left.\mathrm{MeNH}_{3} \mathrm{Cl}\right)^{9}$ as amidification reagents unfortunately led to the degradation of substrate $\mathbf{2 3}$ (Scheme 9).

Attempts utilizing a two-step procedure using a saponification followed by an amidification also failed. Indeed neither harsh conditions $\left(\mathrm{KOH}, \mathrm{EtOH} / \mathrm{H}_{2} \mathrm{O}\right.$, reflux) nor soft conditions (NaOH $1 \mathrm{M}, \mathrm{THF} / \mathrm{MeOH}, \mathrm{rt}$ ) led to the desired carboxylic acid 24. A degradation of the substrate was also observed along with the loss of the fluorine atom (Scheme 10).

As the benzylic position of the fluorine atom seems to decrease the energy of the C-F bond and entailed unwanted degradation, the introduction of the fluorine atom and the methyl amide present in LY503430, were planned at a late stage of the synthesis e.g. from 20. The transformation of the methyl ester in $\mathbf{2 0}$ to a methyl amide was realized in one step using Weinreb's conditions. ${ }^{9}$ Treatment of $\mathbf{2 0}$ with 2.0 equiv of MeAlCINHMe (obtained by reaction of $\mathrm{AlMe}_{3} \mathrm{MeNH}_{3} \mathrm{Cl}$ ) allowed the transformation of the methyl ester to a $\mathrm{N}$-methyl amide, however the replacement of the allylamine by a $N$-methylamine was observed and compound 25 was isolated in 70\% yield (Scheme 11). The formation of $\mathbf{2 5}$ could result from the activation of the hydroxyl group by MeAlCINHMe to furnish intermediate 26. The anchimeric assistance of the nitrogen atom associated with the nucleophilic displacement of the $\mathrm{MeNH}-\mathrm{Al}-\mathrm{O}$ moiety could entail an intramolecular rearrangement resulting in the formation of $\mathbf{2 5}$ (Scheme 11, route a). This rearrangement could also be the result of the formation of aziridinium 26' (Scheme 11, route $b$ ), similar to the one formed during the rearrangement of amino alcools induced by DAST. ${ }^{4,10-15}$ 
<smiles>COC(=O)c1ccc(-c2ccc(C(C)(N)CO)cc2)cc1</smiles>

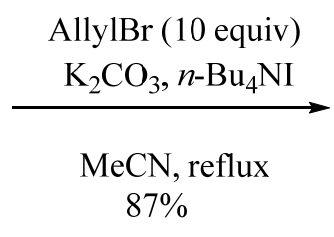<smiles>COC(=O)c1ccc(-c2ccc([C@](C)(N)CO)cc2)cc1</smiles><smiles>COC(=O)c1ccc(-c2ccc(C(C)(F)CN)cc2)cc1</smiles><smiles>CC(C)[PH2+][Mg]</smiles>

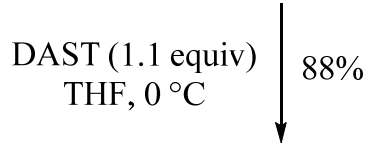
\begin{tabular}{c|c}
$i \mathrm{PrSO}_{2} \mathrm{Cl}(1.5$ equiv $)$ & $30 \%$ \\
$\mathrm{Et}_{3} \mathrm{~N}(3$ equiv $)$ & $\left(t_{\mathrm{c}}\right.$ of $\left.\mathbf{2 2}=44 \%\right)$ \\
$\mathrm{DMAP}, \mathrm{CH}_{2} \mathrm{Cl}_{2}$ &
\end{tabular}<smiles>COC(=O)c1ccc(-c2ccc(C(C)CNC(=O)O)cc2)cc1</smiles>

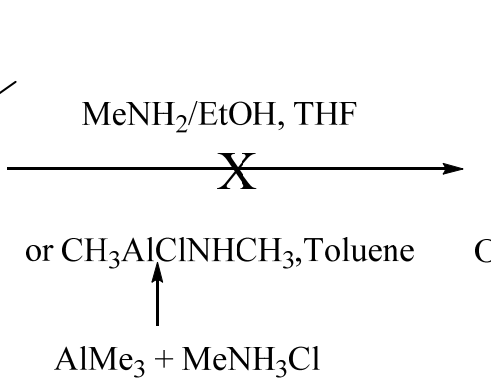<smiles>CNC(=O)c1ccc(-c2ccc(C(C)(F)CNS(=O)(=O)C(C)C)cc2)cc1</smiles>

Scheme 9. Synthesis of sulfonamide 23.

As a consequence, the transformation of $\mathbf{2 0}$ to the corresponding amide was realized in two steps. After saponification of the ester group $(\mathrm{NaOH} 1 \mathrm{M} / \mathrm{THF}=1: 1)$ and amidification of the resulting carboxylic acid $\left(\mathrm{MeNH}_{3} \mathrm{Cl}, \mathrm{HOBt}, \mathrm{EDCI}, \mathrm{Et}_{3} \mathrm{~N}, \mathrm{DMF}\right)$, compound 27 was isolated in $74 \%$ yield and with an enantiomeric excess of $97 \%$. The key rearrangement, to obtain the desired $\beta$-fluoroamine, was then performed by treating 27 with DAST $\left(1.1\right.$ equiv) in THF $\left(0{ }^{\circ} \mathrm{C}, 1 \mathrm{~h}\right)$ producing fluoroamine 28 in $87 \%$ yield and with an enantiomeric excess of $94 \%$. To complete the synthesis of LY503430, the amino group in $\mathbf{2 8}$ was deprotected using $\operatorname{Pd}(\mathrm{dba})_{2}$ in the presence of thiosalicylic acid and 1,4-bis(diphenylphosphino)butane (DPPB) in THF, ${ }^{16}$ the 
resulting amine 29 ( $88 \%$ yield) was then sulfonylated $\left(i \mathrm{PrSO}_{2} \mathrm{Cl}, \mathrm{Et}{ }_{3} \mathrm{~N}, \mathrm{DMAP}, \mathrm{CH}_{2} \mathrm{Cl}_{2}, \tau_{\mathrm{c}}\right.$ of 29 $=30 \%$, corrected yield $73 \%$ ) producing LY503430 (Scheme 12). ${ }^{4}$
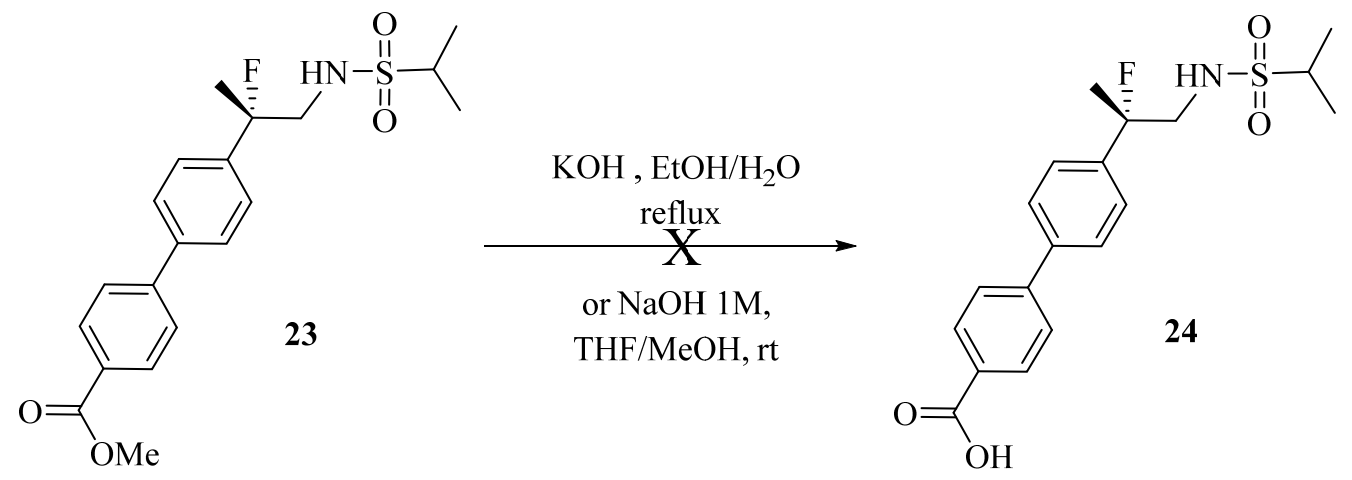

Scheme 10. Saponification test of 23.
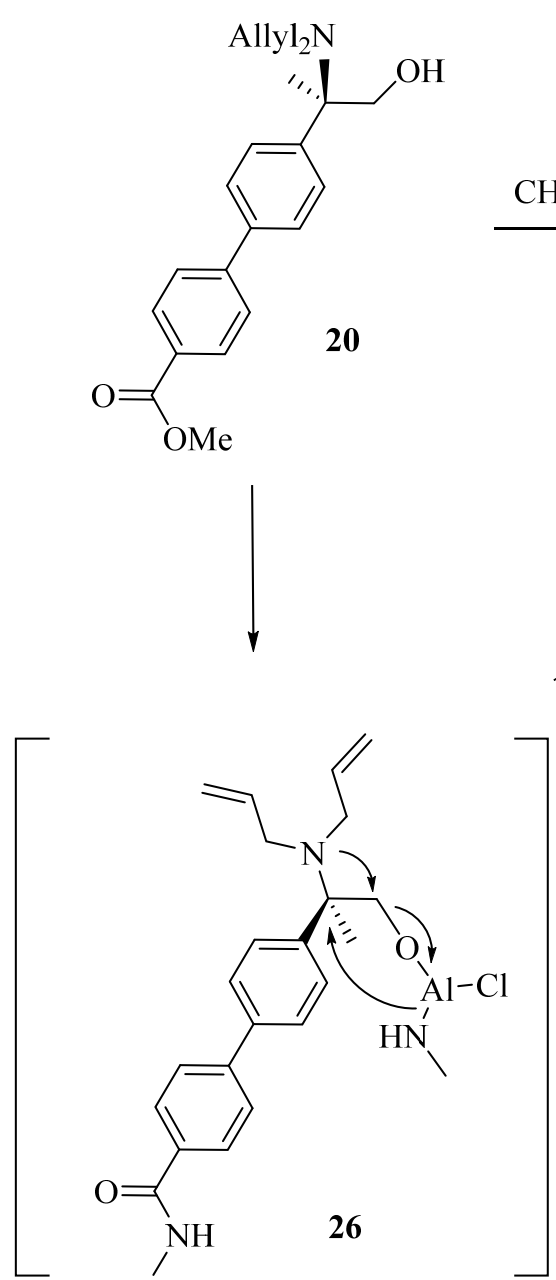

$\mathrm{AlMe}_{3}+\mathrm{MeNH}_{3} \mathrm{Cl}$
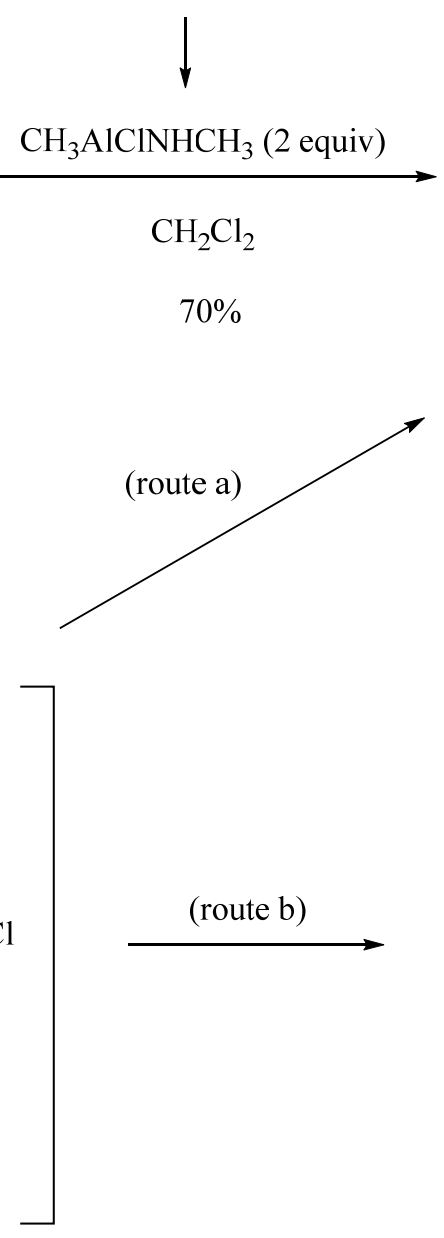

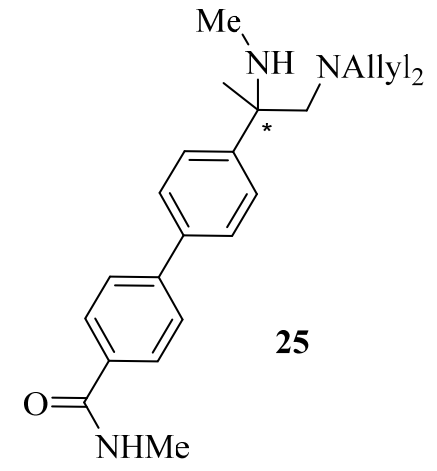

(route b)

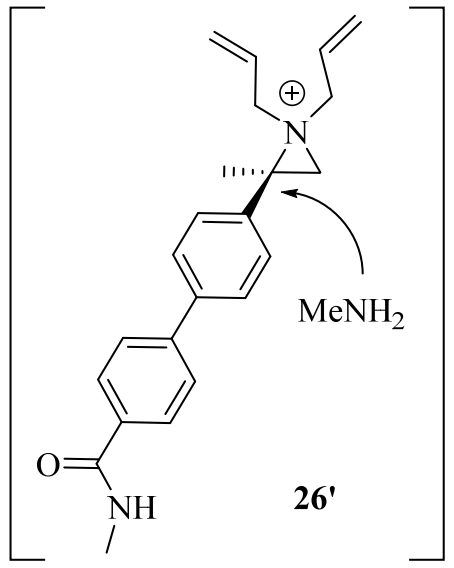

Scheme 11. Synthesis of amide 25. 


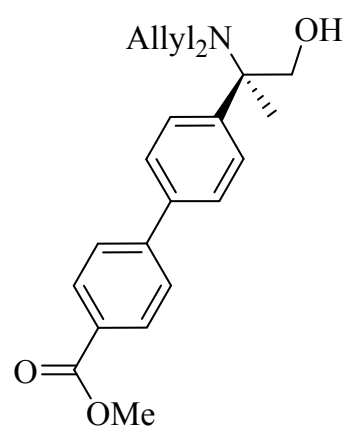

20

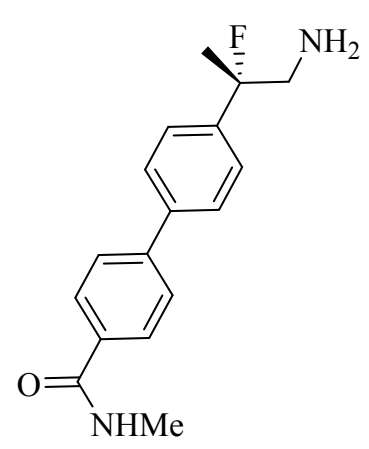

29
1) $\mathrm{NaOH} 1 \mathrm{M} / \mathrm{THF}(1: 1)$ reflux

2) $\mathrm{MeNH}_{3} \mathrm{Cl}$, HOBt, EDCI $\mathrm{Et}_{3} \mathrm{~N}, \mathrm{DMF}, \mathrm{rt}$ $74 \%$<smiles>CNC(=O)c1ccc(-c2ccc([C@@](C)(N)CO)cc2)cc1</smiles>

$27(\mathrm{ee}=97 \%)$

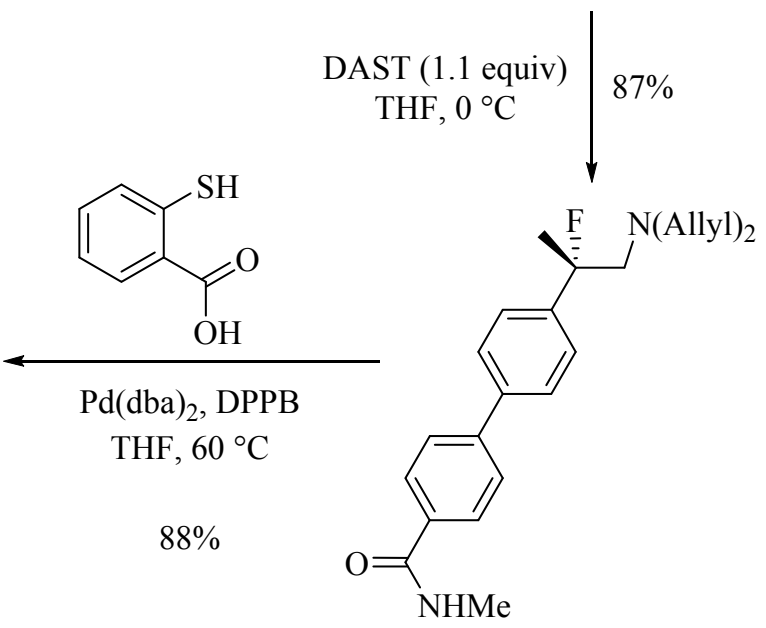

$28($ ee $=94 \%)$

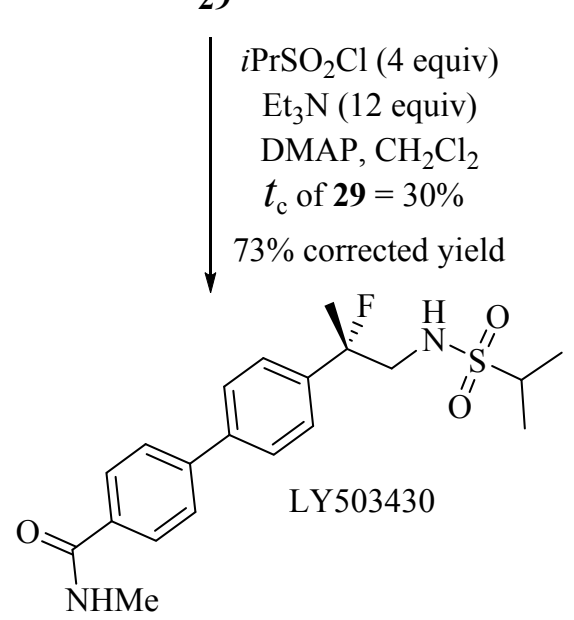

Scheme 12. Synthesis of amide LY503430.

The spectroscopic data as well as the $\alpha_{\mathrm{D}}\left[\alpha_{\mathrm{D}}+27.7,(c 0.1, \mathrm{MeOH})\right]$ were in perfect agreement with those previously reported in the litterature $\left[\alpha_{\mathrm{D}}+31.0,(c 1.0, \mathrm{MeOH})\right]^{2}$ 


\section{Conclusion}

The synthesis of LY503430 was achieved successfully from 4-hydroxy-D-phenylglycine in 14 steps with an overall yield of $8.1 \%$. The key steps were the construction of the quaternary center through a diastereoselective alkylation, a Suzuki coupling to introduce the biarylic function and the rearrangement induced by DAST to obtain the chiral $\beta$-fluoroamine moiety.

It is worth noting that this highly enantio- and regioselective rearrangement is sensitive to the nature of the substituents present on the aromatic ring(s) of aryl or bis-aryl amino alcohols.

\section{Experimental Section}

General. Experimental procedure for the synthesis of compounds 2, 2', 3, 4, 12, 14, 15, 20, 2729 and LY503430 with copies of their ${ }^{1} \mathrm{H}$ and ${ }^{13} \mathrm{C}$ NMR spectra were previously reported. ${ }^{4} \mathrm{H}$ NMR spectra were recorded on a Bruker AVANCE 400 at $400 \mathrm{MHz}$ and data are reported as follows: chemical shift in ppm from tetramethylsilane as internal standard, multiplicity ( $\mathrm{s}=$ singulet, $\mathrm{d}=$ doublet, $\mathrm{t}=$ triplet, $\mathrm{q}=$ quartet, $\mathrm{m}=$ multiplet or overlap of non-equivalent resonances, integration). ${ }^{13} \mathrm{C}$ NMR spectra were recorded on a Bruker AVANCE 400 at 100 $\mathrm{MHz}$ and data are reported as follows: chemical shift in ppm from tetramethylsilane with the solvent as internal standard $\left(\mathrm{CDCl}_{3}, \delta 77.0 \mathrm{ppm}\right)$, multiplicity with respect to proton (deduced from DEPT experiments, $\mathrm{s}=$ quaternary $\mathrm{C}, \mathrm{d}=\mathrm{CH}, \mathrm{t}=\mathrm{CH}_{2}, \mathrm{q}=\mathrm{CH}_{3}$ ). Mass spectra with electronic impact (MS-EI) were recorded from a Hewlett-Packard tandem 5890A GC (12 m capillary column) $-5971 \mathrm{MS}(70 \mathrm{eV})$. Infrared (IR) spectra were recorded on a Bruker TENSOR $^{\mathrm{TM}} 27$ (IRFT), wave-numbers are indicated in $\mathrm{cm}^{-1}$. THF was distilled from sodiumbenzophenone. Reagents obtained from commercial suppliers were used as received. TLC was performed on Merck $60 \mathrm{~F}_{254}$ silica gel plates and visualized with a UV lamp (254 nm), or by using solutions of $\mathrm{KMnO}_{4} / \mathrm{K}_{2} \mathrm{CO}_{3} / \mathrm{NaOH}$ in water or by using $p$-anisaldehyde/sulfuric acid/acetic acid in EtOH followed by heating. Column chromatography was performed with Merck Geduran Si 60 silica gel $(40-63 \mu \mathrm{m})$. High resolution mass spectra (HRMS) were performed by the centre regional de microanalyse (Université Pierre et Marie Curie Paris VI).

General procedure for rearrangement of $\beta$-aminoalcohols induced by DAST. To a solution of $\beta$-amino alcohol of type $\mathbf{B}$ in THF $(0.05 \mathrm{M})$ was added DAST (1.1 to 2.2 equiv) at $0{ }^{\circ} \mathrm{C}$. The mixture was stirred for $1 \mathrm{~h}$ at $0{ }^{\circ} \mathrm{C}$ and then warmed to rt. After addition of $\mathrm{H}_{2} \mathrm{O}$, the mixture was extracted with twice $\mathrm{CH}_{2} \mathrm{Cl}_{2}$, dried over $\mathrm{MgSO}_{4}$, filtered and concentrated under reduced pressure. Purification of the residue by flash chromatography on silica gel afforded $\beta$-fluoroamines of type $\mathbf{C}$.

(R)-2-(4-(Benzyloxy)phenyl)-2-( $N, N$-dibenzylamino)propan-1-ol (8). To a solution of 9 (280 $\mathrm{mg}, 0.99 \mathrm{mmol}, 1.0$ equiv) in $\mathrm{EtOH} / \mathrm{H}_{2} \mathrm{O}(10 \mathrm{~mL} / 10 \mathrm{~mL})$ was added $\mathrm{LiOH}(1 \mathrm{~g}, 42 \mathrm{mmol}, 42$ 
equiv). After $18 \mathrm{~h}$ at reflux, EtOH was evaporated and the aqueous phase was extracted with EtOAc $(2 \times 20 \mathrm{~mL})$. The combined organic layers were dried over $\mathrm{MgSO}_{4}$, filtered and concentrated under reduced pressure to give $10(234 \mathrm{mg}, 0.91 \mathrm{mmol}, 92 \%$ crude yield). The residue was dissolved in $\mathrm{MeCN}(10 \mathrm{~mL})$ and $\mathrm{K}_{2} \mathrm{CO}_{3}$ (378 $\mathrm{mg}, 2.73 \mathrm{mmol}, 3.0$ equiv), $n$ - $\mathrm{Bu} 4 \mathrm{NI}$ (100 mg, 0.27 mmol, 0.3 equiv) and $\operatorname{BnBr}(240 \mu \mathrm{L}, 2.0 \mathrm{mmol}, 2.2$ equiv) were added. After $6 \mathrm{~h}$ at reflux, $\mathrm{MeCN}$ was evaporated and the residue was dissolved in $\mathrm{H}_{2} \mathrm{O}$ /EtOAc. The aqueous phase was extracted with EtOAc $(2 \times 20 \mathrm{~mL})$, the combined organic layers were dried over $\mathrm{MgSO}_{4}$, filtered and concentrated under reduced pressure. Purification of the residue by flash chromatography on silica gel (petroleum ether/EtOAc 90/10) afforded 8 (333 mg, $0.76 \mathrm{mmol}$, $77 \%)$ as a colorless oil. $[\alpha]_{\mathrm{D}}{ }^{25}+61.3\left(c 1.0, \mathrm{CHCl}_{3}\right)$; IR (neat): $3500-2500,1605,1508,1240$, $1025,828 \mathrm{~cm}^{-1} ;{ }^{1} \mathrm{H}$ NMR $\left(400 \mathrm{MHz}, \mathrm{CDCl}_{3}\right): \delta 7.61(\mathrm{~d}, J 8.8 \mathrm{~Hz}, 2 \mathrm{H}), 7.45-7.11(\mathrm{~m}, 15 \mathrm{H}), 7.01$ $(\mathrm{d}, J 8.8 \mathrm{~Hz}, 2 \mathrm{H}), 5.06(\mathrm{~s}, 2 \mathrm{H}), 3.70(\mathrm{~d}, J 14.5 \mathrm{~Hz}, 2 \mathrm{H}), 3.62(\mathrm{~d}, J 14.5 \mathrm{~Hz}, 2 \mathrm{H}), 3.50(\mathrm{~d}, J 11.1$ $\mathrm{Hz}, 1 \mathrm{H}), 3.46(\mathrm{~d}, J 11.2 \mathrm{~Hz}, 1 \mathrm{H}), 1.54(\mathrm{~s}, 3 \mathrm{H}), 1.43$ (br s, $\left.1 \mathrm{H}, \mathrm{H}_{\text {alcool }}\right) ;{ }^{13} \mathrm{C}$ NMR $(100 \mathrm{MHz}$, $\mathrm{CDCl}_{3}$ ): $\delta 157.9(\mathrm{~s}), 141.5$ (s, 2C), 137.1 (s), 136.9 (s), 128.7 (d, 2C), $128.6(\mathrm{~d}, 2 \mathrm{C}), 128.5(\mathrm{~d}$, 4C), $128.2(\mathrm{~d}, 4 \mathrm{C}), 128.0(\mathrm{~d}), 127.6(\mathrm{~d}, 2 \mathrm{C}), 126.8(\mathrm{~d}, 2 \mathrm{C}), 114.5(\mathrm{~d}, 2 \mathrm{C}), 70.1(\mathrm{t}), 70.1(\mathrm{t}), 66.1$ (s), 54.2 (t, 2C), 15.6 (q); HRMS Calcd for $\mathrm{C}_{30} \mathrm{H}_{32} \mathrm{NO}_{2}\left(\mathrm{M}+\mathrm{H}^{+}\right)$: 438.2427; Found: 438.2426.

(R)-4-(4-(Benzyloxy)phenyl)-4-méthyloxazolidin-2-one (9). To a solution of 4 (520 mg, 2.7 mmol, 1.0 equiv) in acetone $(10 \mathrm{~mL})$, were added $\mathrm{K}_{2} \mathrm{CO}_{3}(410 \mathrm{mg}, 3.0 \mathrm{mmol}, 1.1$ equiv) and $\operatorname{BnBr}(350 \mu \mathrm{L}, 3.0 \mathrm{mmol}, 1.1$ equiv). After $4 \mathrm{~h}$ at reflux, the solution was concentrated under vacuum, the residue was dissolved in EtOAc and a solution of $\mathrm{HCl} 1 \mathrm{M}$ was added. The aqueous phase was extracted with $\mathrm{CH}_{2} \mathrm{Cl}_{2}$, the combined organic layers were dried over $\mathrm{MgSO}_{4}$, filtered and concentrated under reduced pressure. Crystallisation of the residue in pentane afforded 9 (706 mg, $2.5 \mathrm{mmol}, 93 \%)$ as a white solid. $[\alpha]_{\mathrm{D}}{ }^{25}-51.9\left(c 1.0, \mathrm{CHCl}_{3}\right) ; \mathrm{mp} 148-150{ }^{\circ} \mathrm{C}$; IR (neat): $3203,1762,1512,1387,1245,1183,1013,837 \mathrm{~cm}^{-1} ;{ }^{1} \mathrm{H}$ NMR $\left(400 \mathrm{MHz}, \mathrm{CDCl}_{3}\right): \delta$ 7.43-7.26 (m, 7H), 6.98 (d, J 9.0 Hz, 2H), 6.27 (s, 1H, $\left.\mathrm{H}_{\text {amide }}\right), 5.06$ (s, 2H), 4.33 (d, J $8.4 \mathrm{~Hz}$, $1 \mathrm{H}), 4.30(\mathrm{~d}, J 8.3 \mathrm{~Hz}, 1 \mathrm{H}), 1.72(\mathrm{~s}, 3 \mathrm{H}) ;{ }^{13} \mathrm{C} \mathrm{NMR}\left(100 \mathrm{MHz}, \mathrm{CDCl}_{3}\right): \delta 159.2(\mathrm{~s}), 158.4(\mathrm{~s})$, 136.7 (s), 135.7 (s), 128.7 (d, 2C), 128.1 (d), 127.5 (d, 2C), 126.0 (d, 2C), 115.2 (s, 2C), $78.4(\mathrm{t})$, 70.1 (t), 60.0 (s), 27.6 (q). MS-EI m/z (\%): $283\left(\mathrm{M}^{+\bullet}, 8\right), 268$ (4), 207 (3), 91 (100), 65 (8). HRMS Calcd for $\mathrm{C}_{17} \mathrm{H}_{17} \mathrm{NaNO}_{3}\left(\mathrm{M}+\mathrm{Na}^{+}\right)$: 306.1100; Found: 306.1101 .

(S)-N,N-Dibenzyl-2-(4-(benzyloxy)phenyl)-2-fluoropropan-1-amine (11). Following the general procedure, amino alcool $8(100 \mathrm{mg}, 0.23 \mathrm{mmol}, 1.0$ equiv) was treated with DAST (45 $\mu \mathrm{L}, 0.34 \mathrm{mmol}, 1.5$ equiv) during $1.5 \mathrm{~h}$ at $0{ }^{\circ} \mathrm{C}$, to furnish 11 (99 mg, $0.34 \mathrm{mmol}, 99 \%$ crude yield). Analyses were realized on the crude residue. IR (neat): 3030, 1674, 1600, 1509, 1453, 1243, 1025, $831 \mathrm{~cm}^{-1} ;{ }^{1} \mathrm{H}$ NMR $\left(400 \mathrm{MHz}, \mathrm{CDCl}_{3}\right): \delta 7.45-7.11(\mathrm{~m}, 15 \mathrm{H}), 7.10(\mathrm{~d}, J 8.6 \mathrm{~Hz}$, 2H), 6.90 (d, J 8.4 Hz, 2H), 5.06 (s, 2H), 3.72 (br s, 2H), 3.56 (br s, 2H), 2.84 (br s, 2H), 1.59 (d, $J 23.1 \mathrm{~Hz}, 3 \mathrm{H}$ ); ${ }^{13} \mathrm{C} \mathrm{NMR}\left(100 \mathrm{MHz}, \mathrm{CDCl}_{3}\right): \delta 158.0(\mathrm{~s}), 139.6(\mathrm{~s}), 137.0(\mathrm{~s}, 2 \mathrm{C}), 136.6(\mathrm{~s})$, 129.0 (d, 2C), 128.6 (d, 4C), $128.2(\mathrm{~d}, 4 \mathrm{C}), 128.0$ (d), 127.5 (d, 2C), 126.9 (d, 2C), 125.8 (d, 2C), $114.4(\mathrm{~d}, 2 \mathrm{C}), 99.5(\mathrm{ds}, J 200.9 \mathrm{~Hz}), 70.1(\mathrm{t}), 62.5(\mathrm{t}), 59.5$ (t, 2C), 25.3 (qd, J 37.5 Hz).

(R)-Methyl-4'-(2-( $N, N$-Dibenzylamino)-1-hydroxypropan-2-yl) biphenyl-4-carboxylate (16). To a solution of $\mathbf{1 5}\left(110 \mathrm{mg}, 0.39 \mathrm{mmol}, 1.0\right.$ equiv) in $\mathrm{MeCN}(5 \mathrm{~mL})$ were added $\mathrm{K}_{2} \mathrm{CO}_{3}(160 \mathrm{mg}$, 
1.16mmol, 3.0 equiv), $n \mathrm{Bu}_{4} \mathrm{NI}$ (43 mg, 0.12, 0.3 equiv) and $\mathrm{BnBr}(101 \mu \mathrm{L}, 0.85 \mathrm{mmol}, 2.2$ equiv). After $9 \mathrm{~h}$ at reflux, $\mathrm{MeCN}$ was evaporated and the residue dissolved in $\mathrm{H}_{2} \mathrm{O}$ /EtOAc. The aqueous phase was extracted with EtOAc, the combined organic layers are dried on $\mathrm{MgSO}_{4}$, filtered and concentrated under reduced pressure. Purification of the residue by flash chromatography on silica gel (petroleum ether/EtOAc 80/20) afforded $16(134 \mathrm{mg}, 0.29 \mathrm{mmol}, 75 \%)$ as a colorless oil. $[\alpha]_{\mathrm{D}}{ }^{25}+93.8\left(c 0.50, \mathrm{CHCl}_{3}\right)$; IR (neat): 3500-2800, 1704, 1606, 1439, 1281, 1113, 1026, $832 \mathrm{~cm}^{-1}$; ${ }^{1} \mathrm{H}$ NMR $\left(400 \mathrm{MHz}, \mathrm{CDCl}_{3}\right): \delta 8.03(\mathrm{~d}, J 8.0 \mathrm{~Hz}, 2 \mathrm{H}), 7.73(\mathrm{~d}, J 8.8 \mathrm{~Hz}, 2 \mathrm{H}), 7.61-$ $7.58(\mathrm{~m}, 4 \mathrm{H}), 7.22-7.06(\mathrm{~m}, 10 \mathrm{H}), 3.86(\mathrm{~s}, 3 \mathrm{H}), 3.67(\mathrm{~d}, J 14.5 \mathrm{~Hz}, 2 \mathrm{H}), 3.61(\mathrm{~d}, J 14.6 \mathrm{~Hz}, 2 \mathrm{H})$, $3.51(\mathrm{~d}, J 11.2 \mathrm{~Hz}, 1 \mathrm{H}), 3.46(\mathrm{~d}, J 10.9 \mathrm{~Hz}, 1 \mathrm{H}), 1.54(\mathrm{~s}, 3 \mathrm{H}) ;{ }^{13} \mathrm{C} \mathrm{NMR}\left(100 \mathrm{MHz}, \mathrm{CDCl}_{3}\right): \delta$ 167.0 (s), 145.2 (s), 145.1 (s), 141.3 (s, 2C), 138.7 (s), 130.1 (d, 2C), 128.9 (s), 128.5 (d, 4C), $128.3(\mathrm{~d}, 4 \mathrm{C}), 128.1(\mathrm{~d}, 2 \mathrm{C}), 127.1(\mathrm{~d}, 2 \mathrm{C}), 127.0$ (d, 2C), 126.9 (d, 2C), $69.9(\mathrm{t}), 65.5(\mathrm{~s}), 54.3$ (t, 2C), 52.2 (q), 15.5 (q). MS-EI m/z (\%): $268\left(\mathrm{M}^{+\bullet}-\mathrm{Bn}_{2} \mathrm{NH}, 17\right), 239$ (100), 180 (18), 165 (24), 152 (10), 59 (19). HRMS Calcd for $\mathrm{C}_{31} \mathrm{H}_{32} \mathrm{NO}_{3}\left(\mathrm{M}+\mathrm{H}^{+}\right)$: 466.2376; Found: 466.2376.

(S)-Methyl-4'-(1-( $N, N$-Dibenzylamino)-2-fluoropropan-2-yl)biphenyl-4-carboxylate (17).

Following the general procedure, amino alcool $16(52 \mathrm{mg}, 0.11 \mathrm{mmol}, 1.0$ equiv) was treated with DAST $\left(18 \mu \mathrm{L}, 0.11 \mathrm{mmol}, 1.1\right.$ equiv) for $1 \mathrm{~h}$ at $0{ }^{\circ} \mathrm{C}$, to furnish an oil which was purified by flash chromatography on silica gel (petroleum ether/EtOAc 96/4) to give 17 (41 mg, 0.09mmol, $78 \%$ ) as a colorless oil. $[\alpha]_{\mathrm{D}}{ }^{25}-84.0\left(c 1.0, \mathrm{CHCl}_{3}\right)$; IR (neat): 2926, 1714, 1608, 1431, 1275, 1100, $832 \mathrm{~cm}^{-1}$; ${ }^{1} \mathrm{H}$ NMR (400 MHz, $\left.\mathrm{CDCl}_{3}\right): \delta 8.04(\mathrm{~d}, J 8.8 \mathrm{~Hz}, 2 \mathrm{H}), 7.59(\mathrm{~d}, J 8.5 \mathrm{~Hz}, 2 \mathrm{H})$, $7.48(\mathrm{~d}, J 8.0 \mathrm{~Hz}, 2 \mathrm{H}), 7.21-7.12(\mathrm{~m}, 12 \mathrm{H}), 3.87(\mathrm{~s}, 3 \mathrm{H}), 3.62(\mathrm{~d}, J 13.5 \mathrm{~Hz}, 2 \mathrm{H}), 3.52(\mathrm{~d}, J 13.6$ Hz, 2H), 2.83 (dd, $J 28.0,14.6 \mathrm{~Hz}, 1 \mathrm{H}), 2.77$ (dd, $J 29.6,14.6 \mathrm{~Hz}, 1 \mathrm{H}), 1.54$ (d, $J 23.1 \mathrm{~Hz}, 3 \mathrm{H})$; ${ }^{13} \mathrm{C} \mathrm{NMR}\left(100 \mathrm{MHz}, \mathrm{CDCl}_{3}\right): \delta 167.0$ (s), $145.2(\mathrm{~s}), 144.1$ (ds, $\left.J 22.3 \mathrm{~Hz}\right), 139.5$ (s, 2C), 138.8 (s), 130.2 (d, 2C), 129.1 (d, 4C), 128.9 (s), 128.1 (d, 4C), 127.0 (d, 2C), 126.9 (d, 4C), 125.2 (dd, $J 9.6 \mathrm{~Hz}, 2 \mathrm{C}$ ), 99.5 (ds, $J 174.3 \mathrm{~Hz}), 62.3$ (dt, $J 21.7 \mathrm{~Hz}$ ), 59.5 (dt, $J 3.6 \mathrm{~Hz}, 2 \mathrm{C}$ ), 52.2 (q), 25.5 (dq, $J 25.0 \mathrm{~Hz}$ ); HRMS Calcd for $\mathrm{C}_{31} \mathrm{H}_{31} \mathrm{~N}_{2} \mathrm{OF}\left(\mathrm{M}+\mathrm{H}^{+}\right)$: 468.2333 ; Found: 468.2330 .

(S)-Methyl 4'-(1-(diallylamino)-2-fluoropropan-2-yl)-biphenyl-4-carboxylate (21).

Following the general procedure, amino alcool 20 (140 $\mathrm{mg}, 0.38 \mathrm{mmol}, 1.0$ equiv) was treated with DAST $\left(55 \mu \mathrm{L}, 0.42 \mathrm{mmol}, 1.0\right.$ equiv) for $1 \mathrm{~h}$ at $0{ }^{\circ} \mathrm{C}$, to furnish an oil which was purified by flash chromatography on silica gel (petroleum ether/EtOAc 95/5) to give 21 (123 mg, 0.34 mmol, 88\%) as a colorless oil. $\quad[\alpha]_{\mathrm{D}}{ }^{25}-5.3\left(c 1.0, \mathrm{CHCl}_{3}\right)$; IR (neat): $2950,1719,11609,1434$, 1276, 1110, 918, 829, $773 \mathrm{~cm}^{-1} ;{ }^{1} \mathrm{H}$ NMR $\left(400 \mathrm{MHz}, \mathrm{CDCl}_{3}\right): \delta 8.02(\mathrm{~d}, J 8.5 \mathrm{~Hz}, 2 \mathrm{H}), 7.58(\mathrm{~d}, J$ $8.5 \mathrm{~Hz}, 2 \mathrm{H}), 7.52(\mathrm{~d}, J 8.3 \mathrm{~Hz}, 2 \mathrm{H}), 7.35(\mathrm{~d}, J 8.5 \mathrm{~Hz}, 2 \mathrm{H}), 5.76-5.66(\mathrm{~m}, 2 \mathrm{H}), 5.06-5.01(\mathrm{~m}$, $4 \mathrm{H}), 3.85$ (s, 3H), 3.14 (dd, $J 13.8,5.3 \mathrm{~Hz}, 2 \mathrm{H}), 3.00$ (dd, $J 13.7,6.1 \mathrm{~Hz}, 2 \mathrm{H}), 2.83-2.67(\mathrm{~m}, 2 \mathrm{H})$, $1.65(\mathrm{~d}, J 22.9 \mathrm{~Hz}, 3 \mathrm{H}) ;{ }^{13} \mathrm{C} \mathrm{NMR}\left(100 \mathrm{MHz}, \mathrm{CDCl}_{3}\right): \delta 167.0(\mathrm{~s}), 145.1$ (s), 144.2 (ds, $J 21.5$ Hz), 138.9 (s), 135.8 (d, 2C), 130.1 (d, 2C), 129.0 (s), 126.9 (d, 2C), 126.9 (d, 2C), 125.2 (dd, J $9.6 \mathrm{~Hz}, 2 \mathrm{C}), 117.3(\mathrm{t}, 2 \mathrm{C}), 98.8(\mathrm{ds}, J 174.0 \mathrm{~Hz}), 62.0(\mathrm{dt}, J 23.1 \mathrm{~Hz}), 58.1$ (dt, $J 2.1 \mathrm{~Hz}, 2 \mathrm{C})$, 52.0 (q), 24.8 (dq, $J 24.6 \mathrm{~Hz}$ ); MS-EI $m / z$ (\%): $347\left(\mathrm{M}^{+\bullet}\right.$-HF, 5), 332 (7), 252 (7), 110 (100), 68 (11); HRMS Calcd for $\mathrm{C}_{23} \mathrm{H}_{27} \mathrm{FNO}_{2}\left(\mathrm{M}+\mathrm{H}^{+}\right)$: 368.2020; Found: 368.2022.

(S)-Methyl 4'-(1-amino-2-fluoropropan-2-yl)-biphenyl-4-carboxylate (22). To a solution of 21 (123 mg, $0.34 \mathrm{mmol}, 1.0$ equiv) in $\mathrm{CH}_{2} \mathrm{Cl}_{2}(4 \mathrm{~mL})$ were successively added NMDBA 
(314 mg, 2.0 mmol, 6.0 equiv) and $\mathrm{Pd}\left(\mathrm{PPh}_{3}\right)_{4}(40 \mathrm{mg}, 0.03 \mathrm{mmol}, 0.1$ equiv). After $2 \mathrm{~h}$ of stirring at $35{ }^{\circ} \mathrm{C}$, the solution was concentrated and the residue dissolved in $\mathrm{Et}_{2} \mathrm{O} / \mathrm{EtOAc}$ 1:1 $(15 \mathrm{~mL})$. The organic phase was washed 5 times with an aqueous saturated solution of $\mathrm{Na}_{2} \mathrm{CO}_{3}$, dried on $\mathrm{Na}_{2} \mathrm{SO}_{4}$ and concentrated under reduced pressure. Purification of the residue by flash chromatography on silica gel (EtOAc/MeOH 90/10 $\left.+0.5 \% \mathrm{Et}_{3} \mathrm{~N}\right)$ afforded $22(69 \mathrm{mg}$, $0.24 \mathrm{mmol}, 73 \%)$ as a yellow oil. $[\alpha]_{\mathrm{D}}{ }^{25}+11.3\left(c 1.0, \mathrm{CH}_{2} \mathrm{Cl}_{2}\right)$; IR (neat): $2948,1711,1607$, 1442, 1280, 1114, 831, $772 \mathrm{~cm}^{-1}$; ${ }^{1} \mathrm{H}$ NMR (400 MHz, $\left.\mathrm{CDCl}_{3}\right): \delta 8.04(\mathrm{~d}, J 8.4 \mathrm{~Hz}, 2 \mathrm{H}), 7.59$ (d, $J 8.4 \mathrm{~Hz}, 2 \mathrm{H}), 7.57(\mathrm{~d}, J 8.4 \mathrm{~Hz}, 2 \mathrm{H}), 7.36(\mathrm{~d}, J 8.4 \mathrm{~Hz}, 2 \mathrm{H}), 3.87(\mathrm{~s}, 3 \mathrm{H}), 3.04-2.98(\mathrm{~m}, 2 \mathrm{H})$, $1.61(\mathrm{~d}, J 22.4 \mathrm{~Hz}, 3 \mathrm{H}) ;{ }^{13} \mathrm{C}$ NMR (100 MHz, $\left.\mathrm{CDCl}_{3}\right): \delta 167.0$ (s), 145.0 (s), 142.7 (ds, $J 22.1$ Hz), 139.2 (s), 130.2 (d, 2C), 129.1 (s), 127.4 (d, 2C), 127.0 (d, 2C), 125.1 (dd, J 9.6 Hz, 2C), 98.1 (ds, $J 172.6 \mathrm{~Hz}$ ), 52.2 (dt, $J 24.3 \mathrm{~Hz}$ ), 52.1 (q), 25.0 (dq, $J$ 24.8Hz); HRMS Calcd for $\mathrm{C}_{17} \mathrm{H}_{19} \mathrm{~F} \mathrm{~N} \mathrm{O}_{2}\left(\mathrm{M}+\mathrm{H}^{+}\right)$: 288.1394; Found: 288.1397.

(S)-Methyl 4'-(2-fluoro-1-(1-methylethylsulfonamido)-propan-2-yl)-biphenyl-4-carboxylate (23). To a solution of 22 (22 $\mathrm{mg}, 0.08 \mathrm{mmol}, 1.0$ equiv) and $\mathrm{Et}_{3} \mathrm{~N}$ (33 $\mu \mathrm{L}, 0.24 \mathrm{mmol}, 3.0$ equiv) in $\mathrm{CH}_{2} \mathrm{Cl}_{2}(1 \mathrm{~mL})$ was slowly added at $0{ }^{\circ} \mathrm{C} i-\mathrm{PrSO}_{2} \mathrm{Cl}(13 \mu \mathrm{L}, 0.12 \mathrm{mmol}, 1.5$ equiv $)$. After $18 \mathrm{~h}$ of stirring at $\mathrm{rt}, \mathrm{H}_{2} \mathrm{O}$ was added and the solution extracted with $\mathrm{CH}_{2} \mathrm{Cl}_{2}$. The organic phase was dried on $\mathrm{Na}_{2} \mathrm{SO}_{4}$, filtered and concentrated under reduced pressure. Purification of the residue by flash chromatography on silica gel (petroleum ether/EtOAc 70/30) afforded 23 (9 mg, $0.023 \mathrm{mmol}, 30 \%)$ as a white solid. $[\alpha]_{\mathrm{D}}{ }^{25}+25.2\left(\mathrm{c} 0.5, \mathrm{CHCl}_{3}\right) ; \mathrm{mp} 148-150{ }^{\circ} \mathrm{C} ;{ }^{1} \mathrm{H}$ NMR $\left(400 \mathrm{MHz}, \mathrm{CDCl}_{3}\right): \delta 8.04(\mathrm{~d}, J 8.7 \mathrm{~Hz}, 2 \mathrm{H}), 7.58(\mathrm{~d}, J 8.5 \mathrm{~Hz}, 4 \mathrm{H}), 7.38(\mathrm{~d}, J 8.5 \mathrm{~Hz}, 2 \mathrm{H}), 4.23$ (t, $\left.J 6.3 \mathrm{~Hz}, 1 \mathrm{H}, \mathrm{H}_{\text {sulfonamide }}\right), 3.88(\mathrm{~s}, 3 \mathrm{H}), 3.61-3.45(\mathrm{~m}, 2 \mathrm{H}), 2.99$ (sept, $\left.J 6.8 \mathrm{~Hz}, 1 \mathrm{H}\right), 1.70$ (d, $J$ $22.6 \mathrm{~Hz}, 3 \mathrm{H}), 1.24$ (d, $J 7.0 \mathrm{~Hz}, 3 \mathrm{H}), 1.21(\mathrm{~d}, J 6.8 \mathrm{~Hz}, 3 \mathrm{H}) ;{ }^{13} \mathrm{C} \mathrm{NMR}\left(100 \mathrm{MHz}, \mathrm{CDCl}_{3}\right): \delta$ 166.9 (s), 144.7 (s), 141.3 (ds, J $21.8 \mathrm{~Hz}$ ), 139.9 (s), 130.2 (d, 2C), 129.2 (s), 127.5 (d, 2C), 127.0 (d, 2C), 124.9 (dd, $J 9.5 \mathrm{~Hz}, 2 \mathrm{C}$ ), 96.9 (ds, $J 175.0 \mathrm{~Hz}$ ), 54.0 (d), 52.6 (dt, $J 23.2 \mathrm{~Hz}$ ), 52.2 (q), 24.8 (dq, $J 24.8 \mathrm{~Hz}$ ), 16.6 (q), 16.5 (q); MS-EI m/z (\%): $373\left(\mathrm{M}^{+\bullet}-\mathrm{HF}, 46\right), 342$ (8), 266 (100), 237 (37), 207 (30), 191 (14), 178 (43), 152 (20), 59 (41). HRMS Calcd for $\mathrm{C}_{20} \mathrm{H}_{24} \mathrm{O}_{4} \mathrm{NaFNS}\left(\mathrm{M}+\mathrm{Na}^{+}\right)$: 416.1302 ; Found: 416.1304.

\section{(S)-4'-(1-( $N, N$-Diallylamino)-2-(methylamino)propan-2-yl)- $N$-methylbiphenyl-4-carbox-}

amide (25). To a solution of $\mathrm{MeNH}_{2} \cdot \mathrm{HCl}(68 \mathrm{mg}, 1 \mathrm{mmol}, 1.0$ equiv) in toluene ( $1 \mathrm{~mL})$, was added at $0{ }^{\circ} \mathrm{C}$ a solution of $\mathrm{AlMe}_{3} 2 \mathrm{M}$ in hexane $(0.5 \mathrm{~mL}, 1 \mathrm{mmol}, 1.0$ equiv). The solution was stirred during $1.5 \mathrm{~h}$ at $\mathrm{rt}$ until disappearance of gas emission. To a solution of $20(32 \mathrm{mg}$, $0.088 \mathrm{mmol}, 1.0$ equiv) in $\mathrm{CH}_{2} \mathrm{Cl}_{2}(1 \mathrm{~mL})$ was added a solution of MeAlClNHMe $0.67 \mathrm{M}$ in toluene previously prepared $(260 \mu \mathrm{L}, 0.174 \mathrm{mmol}, 2.0$ equiv). After $12 \mathrm{~h}$ at $\mathrm{rt}$, as no conversion of the starting material was noticed, the solution was stirred under microwave irradiation at $80^{\circ} \mathrm{C}$ for $1 \mathrm{~h}$ then at $100{ }^{\circ} \mathrm{C}$ for $1 \mathrm{~h}$. An aqueous solution of $\mathrm{HCl} 1 \mathrm{M}$ was added to the reaction mixture and the aqueous phase was washed with $\mathrm{CH}_{2} \mathrm{Cl}_{2}$. The aqueous phase was basified with an aqueous solution of $\mathrm{NaOH} 2 \mathrm{M}$ and extracted with EtOAc. The combined organic layers were dried on $\mathrm{MgSO}_{4}$, filtered and concentrated under reduced pressure to give 25 (23 $\mathrm{mg}, 0.061$ mmol, 70\%) as a yellow gum. $[\alpha]_{\mathrm{D}}{ }^{25}+3.3\left(c 1.0, \mathrm{CHCl}_{3}\right)$; IR (neat): 3348, 2993, 2799, 1636, 1550, 1492, 1409, 1303, $917 \mathrm{~cm}^{-1}$; ${ }^{1} \mathrm{H}$ NMR (400 MHz, $\left.\mathrm{CDCl}_{3}\right): \delta 7.76(\mathrm{~d}, J 8.3 \mathrm{~Hz}, 2 \mathrm{H}), 7.58$ 
(d, J $8.3 \mathrm{~Hz}, 2 \mathrm{H}), 7.51(\mathrm{~d}, J 8.5 \mathrm{~Hz}, 2 \mathrm{H}), 7.44(\mathrm{~d}, J 8.5 \mathrm{~Hz}, 2 \mathrm{H}), 6.25$ (m, 1H, $\left.\mathrm{H}_{\text {amide }}\right), 5.72-5.62$ (m, 2H), 5.01-4.96 (m, 4H), $2.96(\mathrm{~d}, J 4.6 \mathrm{~Hz}, 3 \mathrm{H}), 2.93-2.90(\mathrm{~m}, 4 \mathrm{H}), 2.63(\mathrm{~s}, 2 \mathrm{H}), 2.19$ (s, 3H), 1.47 (s, 3H); $\left.{ }^{13} \mathrm{C} \mathrm{NMR} \mathrm{(100} \mathrm{MHz,} \mathrm{CDCl}_{3}\right): \delta 168.0(\mathrm{~s}), 144.4(\mathrm{~s}), 143.7$ (s), $138.0(\mathrm{~s}), 135.5$ (d, 2C), 133.1 (s), 127.5 (d, 2C), 127.4 (d, 2C), 127.0 (d, 2C), 126.8 (d, 2C), 117.3 (t, 2C), 69.2 (t), 60.6 (s), 58.3 (t, 2C), 29.0 (q), 26.9 (q), 22.0 (q); MS-EI m/z (\%): 267 (M ${ }^{+\cdot}-\mathrm{Allyl}_{2} \mathrm{NHCH}_{2}{ }^{\circ}$, 100), 251 (4), 209 (9), 152 (5), 110 (76), 56 (83); HRMS Calcd for $\mathrm{C}_{24} \mathrm{H}_{32} \mathrm{~N}_{3} \mathrm{O}\left(\mathrm{M}+\mathrm{H}^{+}\right)$: 378.2539.; Found: 378.2541.

\section{Acknowledgements}

Sanofi is greatly acknowledged for financial support and for a grant (B. D.).

\section{References}

1. Murray, T. K.; Whalley, K.; Robinson, C. S.; Ward, M. A.; Hicks, C. A.; Caroline, A.; Lodge, D.; Vandergriff, J. L.; Baumbarger, P.; Siuda, E.; Gates, M.; Ogden, A. M. J. Pharmacol. Exp. Ther. 2003, 306, 752-762. http://dx.doi.org/10.1124/jpet.103.049445

2. Magnus, N. A.; Aikins, J. A.; Cronin, J. S.; Diseroad, W. D.; Hargis, A. D.; Letourneau, M. E.; Parker, B. E.; Reutzel-Edens, S. M.; Schafer, J. P.; Staszak, M. A.; Stephenson, G. A.; Tameze, S. L.; Zollars, L. M. H. Org. Process Res. Dev. 2005, 9, 621-628. http://dx.doi.org/10.1021/op0500741

3. For a review of deoxyfluorination reagents see: Al-Maharik, N.; O'Hagan, D. Aldrichimica Acta, 2011, 44, 65-75.

4. Duthion, B.; Gomez Pardo, D.; Cossy, J. Org. Lett. 2010, 12, 4620-4623. http://dx.doi.org/10.1021/ol1019579

5. O’Donnell, M. J.; Fang, Z.; Ma, X.; Huffman, J. C. Heterocycles 1997, 46, 617-630. http://dx.doi.org/10.3987/COM-97-S83

6. (a) For a review of the rearrangement of $\beta$-amino alcohols via an aziridinium see: Métro, T.-X.; Duthion, B.; Gomez Pardo, D.; Cossy, J. Chem. Soc.Rev. 2010, 39, 89-102. (b) For a systematic study of halide-induced ring opening of aziridinium see: D'hooghe, M.; Catak, S.; Stanković, S.; Waroquier, M.; Kim, Y.; Ha, H.-J.; Van Speybroeck, V.; De Kimpe, N. Eur. J. Org. Chem. 2010, 4920-4931 and refererences cited therein. http://dx.doi.org/10.1039/b806985a

7. Nguyen, H. N.; Huang, X.; Buchwald, S. L. J. Am. Chem. Soc. 2003, 125, 11818-11819. http://dx.doi.org/10.1021/ja036947t

8. Garro-Helion, F.; Merzouk, A.; Guibé, F. J. Org. Chem. 1993, 58, 6109-6113. http://dx.doi.org/10.1021/jo00074a044 
9. Levin, J. I.; Turos, E.; Weinreb, S. M. Synth. Comm. 1982, 12, 989-993. http://dx.doi.org/10.1080/00397918208061938

10. Ye, C.; Shreeve, J. M. J. Fluorine Chem. 2004, 125, 1869-1872. http://dx.doi.org/10.1016/j.jfluchem.2004.06.013

11. Déchamps, I.; Gomez Pardo, D.; Cossy, J. Synlett 2007, 263-267.

12. Déchamps, I.; Gomez Pardo, D.; Cossy, J. Eur. J. Org. Chem. 2007, 4224-4234. http://dx.doi.org/10.1002/ejoc.200700237

13. Ferret, H.; Déchamps, I.; Gomez Pardo, D.; Van Hijfte, L.; Cossy, J. ARKIVOC 2010, Viii, $126-159$.

14. Mykhailiuk, P. K.; Shishkina, S. V.; Shishkin, O. V.; Zaporozhets, O. A.; Komarov, I. V. Tetrahedron 2011, 67, 3091-3097. http://dx.doi.org/10.1016/j.tet.2011.02.082

15. Anxionnat, B.; Robert, B.; George, P.; Ricci, G.; Perrin, M.-A.; Gomez Pardo, D.; Cossy, J. J. Org. Chem. 2012, 77, 6087-6099. http://dx.doi.org/10.1021/j0300887u

16. Lemaire-Audoire, S.; Savignac, M.; Genêt, J. P. Tetrahedron Lett. 1995, 36, 1267-1270. http://dx.doi.org/10.1016/0040-4039(95)00003-U 